\title{
The Linkages between Hard Infrastructure, Poverty Reduction, and Rice Prices
}

\section{Surjono $^{a^{*}}$, Fauzul R. Sutikno ${ }^{\text {ab }}$, Veibry W.E. Pratiwi $^{\text {a }}$, Suraya Adnan ${ }^{\mathrm{a}}$}

${ }^{a}$ Universitas Brawijaya, Dept of Urban and Regional Planning, $J$. Mayjen Haryono 167, Malang, Indonesia

${ }^{b}$ Cornell University, Dept. of City and Regional Planning 106 W. Sibley Hall, Ithaca, NY, USA

Received: September 28, 2015/ Accepted: June 01, 2016

\section{Abstract}

Eradicating poverty and hunger has been an important consideration of every government administration in Indonesia since 1945, from the era of President Soekarno to Joko Widodo. Hard infrastructure development is the priority of the current Indonesian Government, aiming to trigger local economic activities, particularly in rural areas. However, at the same time, hard infrastructure development has also triggered housing and industrial estate development that has converted rice fields in Java Island to built-up areas, thereby reducing rice production which is a significant component of food security in Indonesia. Therefore, it is important to explain the effect of infrastructure in Java Island on poverty and analyse the causality between hard infrastructure, poverty indicators and rice prices (representing productivity and affordability of food). Spatial regression was used to formulate the effect of hard infrastructure (roads, clean water, and electricity) on poverty (headcount index, poverty gap index, poverty severity index, and human poverty index). To evaluate the links between infrastructure and poverty to local rice price, path analysis was used in this research. The results of the analysis can be used to propose better strategies for infrastructure development which is targeted to reduce poverty and maintain rice prices at acceptable levels.

Keywords: infrastructure; rural poverty; rice price; food security.

\section{Abbreviations:}

\begin{tabular}{|lll|}
\hline GoI & $:$ & Government of Indonesia \\
GeoDa & $:$ & Geographic Data Analysis \\
HPI & $:$ & Human Poverty Index \\
LISA & $:$ & Local Indicator of Spatial Association \\
MPI & $:$ & Multidimensional Poverty Index \\
SDGs & $:$ & Sustainable Development Goals \\
\hline
\end{tabular}

\section{Introduction}

A relatively high percentage of poor people (headcount) in Indonesia has led the Government of Indonesia (GoI) at all levels to formulate strategy to reduce the number. At the same time they face problems of food security due to the reduction of fertile agricultural land in many regions mainly because of land use conversion. The case study location for this research is the Regency of Malang, East Java Province. The Regency of Malang has targeted to reduce the number of poor families (10.17\% in 2012) by at least $1.5 \%$ per year, which requires focused development in rural areas.

As exemplified by Jouanjen [1], most recent literature focuses on the effect of road infrastructure development on travel costs, then relates the effect of infrastructure to income. Hard infrastructure is claimed to be a tool to support food security in Indonesia [2] together with providing people with skills and savings [3].Van de Walle [4] and Ali \& Pernia [5] also confirm that roads have direct and indirect correlation with poverty reduction. Fan \& Chan-Kang [6], Bryceson, Bradbury, \& Bradbury [7] support this argument that the road network has significant impacts on poverty because of its roles in reducing the cost of logistic transportation from and to rural areas. Other significant types of hard infrastructure which have significant impacts on poverty are water infrastructure [8] and electricity [9]. Poverty as a dependent variable is best viewed from target $1 \mathrm{~A}$ of goal 1 of the Millennium Development Goals which requires poverty reduction not only in headcount but also in reducing the poverty gap and the multidimensional poverty index (MPI) which has lately replaced human poverty index (HPI). The task to achieve this target in Indonesia belongs to the GoI at all levels and their stakeholders.

The second issue is related to the linkage between food security and hard infrastructure. Land conversion in Indonesia is biased towards industrial and urban development at the expense of productive paddy fields [10]. This conversion process has decreased paddy fields from 8.40 million ha in 1993 to 7.80 million ha in 2003. The impact of the conversion, as has also occurred elsewhere: such as in India, Vietnam, and Laos, is a decline in food security $[11 ; 12 ; 13]$. Food security in Indonesia is closely related to rice prices, since higher rice prices will increase the number of people living below the poverty line [2].The rice price in the Regency of Malang varies across districts. In 2013 the highest price at local markets was Rp 9,50o (USD o.78) per kilogram, and the average was $\mathrm{Rp} 8,480$ (USD 0.70 ). The price affects the capacity and consumption structure of poor families in Malang whose consumption expenditure, based on food and non-food consumption, is only up to Rp 257,510 (USD 21.16) per person per month. Therefore, it is important to understand the linkage between the three important variables, i.e. poverty - infrastructure - rice price, in proposing pro-poor policy strategies for infrastructure development in Indonesia.

Based on these problems, the present research had two main objectives. Firstly, it aimed to observe the influence of hard infrastructure on poverty. Infrastructure of roads, clean water supply and electricity were examined to identify their impacts on the four indicators of poverty (headcount index, poverty gap index, poverty severity index, and human poverty index). The headcount index is widely used to show the ratio of poor people to the total population. The poverty gap index indicates the proportion of individuals who fall below a defined poverty line. The poverty severity index measures the squares of the poverty gaps relative to the poverty line. The human poverty index /multidimensional poverty index (MPI), which was first published 
in a 2010 UNDP report, shows the number of people who are multi-dimensionally poor. The second objective of the research was to analyze the effect of infrastructure and poverty (socialeconomic condition) on rice price, particularly on local rice price. This objective aimed to observe the linkage between infrastructure, local rice price, purchasing power of poor family and, indirectly, food security in the observed region.

\section{Research Method}

To observe and analyze the influence of hard infrastructure on poverty, the survey was targeted to 70 villages in the regency, involving 398 respondents from poor families. To evaluate the relationship of infrastructure and poverty indices, spatial multiple regression was utilized using Geographic Data Analysis $\left(\mathrm{GeoDa}^{\mathrm{TM}}\right)$. Eighteen variables of infrastructure were used as independent variables while four poverty indices were the dependent variables. Two tests were employed, i.e.: the significance of all variables and the influence of spatial lag on dependent variables. The significance of the variables was tested using a significance level of o.o5. The model fitted the coefficients of the equations $Y_{1}, Y_{2}, Y_{3}$, $Y_{4}=\rho W+\beta \cdot X_{1}+\beta \cdot X_{2}+\beta \cdot X_{3}+\ldots+\beta \cdot X_{1} 8+v$; where $Y^{\prime}$ 's were poverty indices, $\rho=$ spatial lag autocorrelation parameter, $W=$ spatial weight of the village, $\beta=$ constant number, and $v=$ error vector that contains autocorrelation, and X's are variables of infrastructure. The influence of spatial lag on dependent variables was tested using a spatial autoregressive model, i.e.: if $\mathrm{H} 1: \rho \neq 0$, a spatial lag exists. The model was $\mathrm{y}=\rho \mathrm{Wy}+\mathrm{X} \beta+\mathrm{v}$, where $\mathrm{y}=$ dependent variables, $X=$ independent variables matrix, $\beta=$ regression parameter coefficient vector, $\rho=$ spatial lag autocorrelation coefficient parameter, $u=$ error vector that contains autocorrelation, and $\mathrm{W}=$ spatial weight matrix. GeoDa spatially analyses (Moran's I analysis) the correlation between adjacent observed areas. This analysis compares the observed score for an area with the score of the adjacent area. The spatial autocorrelation score was considered strong, if the scores were grouped in high-high or low-low quadrants. To see the correlation spatially, we used a Local Indicator of Spatial Association (LISA) analysis to show spatial clustering with significant scores (highhigh category) (Figure 1).

\begin{tabular}{|c|c}
\hline $\begin{array}{c}\text { Quadrant 2 } \\
\text { Low - High }\end{array}$ & $\begin{array}{c}\text { Quadrant 1 } \\
\text { High - High }\end{array}$ \\
\hline & \\
\hline Quadrant 3 & Quadrant 4 \\
Low - Low & High - Low \\
&
\end{tabular}

Figure 1 Quadrants of LISA Analysis

To analyze the effect of infrastructure and community's socialeconomic condition on rice price, we firstly used path analysis to test the influence of infrastructure on local rice price. Path analysis distinguishes endogenous and exogenous variables and the model can be visualized using a path diagram [14]. In the path analysis, the smaller the chi-square value the better [15]. The second step was to measure the purchasing capacity of poor families to buy food, carbohydrates (in this case rice). According to the World Bank [16], the proportion of family expenditure used to buy rice indicates the wellbeing of the family. The observed purchasing capacity was then used as one of the indicators of food security in the region. Basically, food security is defined as access to food that meets nutrient need, physically and economically [17]. As a limitation of this study, we only observe rice, since it is the main source of food for Indonesians. An underlying assumption of this research is: if the rice is affordable, then people are able to buy it, so food security is achieved (in accordance with Government Regulation No 68/2002).

\section{Challenges of Indonesia's Development}

Agriculture was once a major economic sector in Indonesia. Many crops, for example rice and sugar, were exported overseas. However, the situation has reversed, and recently these staple products are imported. Today, Indonesia is the third largest rice and sugar importer [18;19]. This shows that development in Indonesia is not sustainable, and to some extent is vulnerable to external shocks. Criticisms have been addressed to ineffective development for rural areas that results in weak competitiveness of crop prices (prices of imported crops are lower than local prices) and low productivity as well as maintaining poverty. Less focus on rural development has contributed to this condition. Sumarto and Suryahadi [20] claimed that agricultural growth of $1 \%$ can reduce poverty by 1.9 percentage points, while industrial growth can only reduce urban poverty with an elasticity of o.o6. These are challenges of Indonesia's rural development: fighting against poverty, while boosting agricultural production and competitiveness.

Rural infrastructure and agricultural development and practices maybe the key to identifying the root causes of rural poverty and to support the achievement of the sustainable development goals (SDGs) in Indonesia. Related to this challenge, the GoI established Act No 6 Year 2014. One of the most important points regarding this act is about the allocation of central government budgets to villages [21]. Variables of rural development should be correlated with variables of poverty, and development initiatives must be based on the outcomes and long term goals to support the SDGs in Indonesia.

\section{The Influences of Infrastructure on Poverty}

Based on the correlation test, no dependent variable correlated to the headcount index. The correlation of dependent variables to the other three indices of poverty is shown in Table 1.

Table 1 Pearson correlation and significance (2 tailed) of infrastructure variables to poverty indices

\begin{tabular}{lccc}
\hline $\begin{array}{l}\text { Infrastructure } \\
\text { variables }\end{array}$ & $\begin{array}{l}\text { Poverty gap } \\
\text { index }\end{array}$ & $\begin{array}{l}\text { Poverty } \\
\text { severity } \\
\text { index }\end{array}$ & $\begin{array}{l}\text { Human } \\
\text { poverty } \\
\text { index }\end{array}$ \\
\hline $\begin{array}{l}\text { Community water } \\
\text { infrastructure }\end{array}$ & $-.400^{* *}$ & $-.367^{* *}$ & \\
State's own & .001 & .002 & \\
enterprise & $-.480^{* *}$ & $-.433^{* *}$ & \\
electricity power & .000 & .000 & \\
Non state's & & & $-.275^{* *}$ \\
electricity power & $460^{* *}$ & $453^{* *}$ & .021 \\
No electricity & .000 & .000 & \\
& $466^{* *}$ & $.455^{* *}$ & .000 \\
Roads (distance, & .000 & $.295^{*}$ \\
medium condition) & & & .013 \\
Clean water source & & & $.300^{* *}$ \\
(traditional well) & & & .012 \\
Clean water source & & & $.037^{*}$ \\
(river) & & & .032 \\
\hline
\end{tabular}

Table 1 shows that 7 (seven) variables of infrastructure correlate to the three indices although at weak to medium correlation. The result of this correlation analysis was then used 
as inputs in the GeoDa modelling. Moran's I and LISA analyses were applied to two alternatives. The first alternative included all villages (70) and the second alternative excluded outlier villages. The result of Moran's I for the three poverty indices is as shown in Table 2.

Table 2 Moran's I score for three indices of poverty

\begin{tabular}{lccc}
\hline Alternatives & $\begin{array}{l}\text { Poverty gap } \\
\text { index }\end{array}$ & $\begin{array}{l}\text { Poverty } \\
\text { severity index }\end{array}$ & $\begin{array}{l}\text { Human } \\
\text { poverty index }\end{array}$ \\
\hline $\begin{array}{l}\text { Including all } \\
\text { villages and }\end{array}$ & $\mathbf{0 , 3 6 3 5}$ & 0,2979 & 0,0684 \\
$\begin{array}{l}\text { variables } \\
\begin{array}{l}\text { Excluding } \\
\text { outlier villages }\end{array}\end{array}$ & 0,3425 & $\mathbf{0 , 3 9 6 1}$ & $\mathbf{0 , 2 7 1 8}$ \\
\hline
\end{tabular}

Differences in the results of Moran's I score for the two alternatives show that the poverty gap was best observed if we included all villages, while poverty severity and human poverty indices were best represented by excluding the outlier villages. The classical regression analysis for "queen" spatial weight to the three indices indicates that no dependent variable had a significant probability score for the human poverty index, therefore modelling for the human poverty index is not considered necessary. Spatial models for poverty gap and poverty severity indices are as follows:

$\mathrm{Y}_{2}=0.3041783 \mathrm{~W}+0.1829313 \mathrm{X} 8-0.09877042 \mathrm{X} 9-$ $0.001400308 \mathrm{X}_{16}+8.304513$; where $\mathrm{Y}_{2}=$ poverty gap index; $\mathrm{W}=$ spatial weight (village); $\mathrm{X} 8=$ distance from village to district $(\mathrm{km})$; $\mathrm{X}_{9}=$ distance from village to the central of regency $(\mathrm{km})$; $\mathrm{X}_{16}=$ state's electricity (households).

Spatial model for the poverty severity index is: $\mathrm{Y}_{3}=0.4072275$ $\mathrm{W}-0.0009018647 \mathrm{X}_{12}-0.0004275554 \mathrm{X}_{16}+1.864418$; where $\mathrm{Y}_{3}=$ poverty severity index; $\mathrm{W}=$ spatial weight (village); $\mathrm{X} 12=$ water (by community); and X16= state's electricity (households)

Spatial maps for Moran's I scores of the two poverty indices are illustrated in Figure 2 and Figure 3.
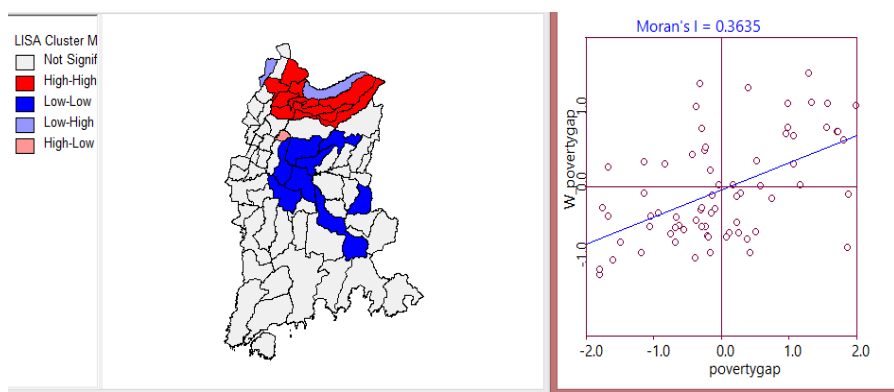

Figure 2 Moran's I for poverty gap index, all villages were included
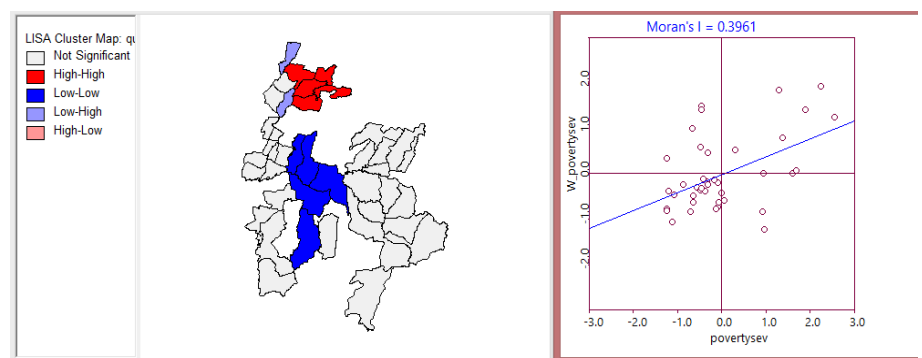

Figure 3 Moran's I score for poverty severity index, outlier villages excluded

\section{The Interrelation of Infrastructure, Poverty, and Rice Price}

The second objective of the research was analyzed by path analysis. The first step of path analysis was to observe the category of the model. The identification was conducted by computing the degrees of freedom which showed a positive score (108), meaning that the model was over-identified and therefore the analysis could be continued. Four requirements for path analysis were fulfilled: valid sampling, the data were normally distributed, no outlier data, and no multi-collinearity, since all correlations among variables were less than o.9 (AMOS outputs). The next step was a goodness-of-fit test $(\mathrm{GoF})$. The result of GoF scores of the path are shown in Table 3.

Table 3 Goodness-of-fit test result

\begin{tabular}{llll} 
GoF Index & Cut-off value & Score & note \\
\hline CMIN/DF & $<2.00$ & 1.035 & Good fit \\
p & $>0.05$ & 0.405 & Good fit \\
RMSEA & $<0.08$ & 0.043 & Good fit \\
GFI & $>0.90$ & 0.934 & Good fit \\
TLI & $>0.90$ & 0.945 & Good fit \\
\hline
\end{tabular}

Table 3 shows that the $\mathrm{p}$ value was $>0.05$ and therefore the model represents actual conditions. A hypothesis test was then conducted by comparing $\mathrm{CR}$ scores in the regression table with $\mathrm{CR}$ scores resulting from AMOS (Table 4).

Table 4 Regression weights

\begin{tabular}{|c|c|c|c|c|c|c|}
\hline & & & $\begin{array}{l}\text { Esti- } \\
\text { mate }\end{array}$ & S.E. & C.R. & $\mathbf{P}$ \\
\hline $\begin{array}{l}\text { Number of } \\
\text { local } \\
\text { cooperative } \\
\text { businesses } \\
\text { (koperasi) }\end{array}$ & $<-$ & $\begin{array}{l}\text { Number of } \\
\text { farmers }\end{array}$ & 0.002 & 0.001 & 2.230 & 0.026 \\
\hline $\begin{array}{l}\text { Number of } \\
\text { local } \\
\text { cooperative } \\
\text { businesses }\end{array}$ & $<-$ & $\begin{array}{l}\text { Rice } \\
\text { production }\end{array}$ & 0.000 & 0.000 & 1.822 & 0.262 \\
\hline $\begin{array}{l}\text { Number of } \\
\text { local } \\
\text { cooperative } \\
\text { businesses }\end{array}$ & $<-$ & $\begin{array}{l}\text { Distance to } \\
\text { city }\end{array}$ & -0.663 & 0.179 & 3.700 & $* * *$ \\
\hline $\begin{array}{l}\text { Number of } \\
\text { poor } \\
\text { families }\end{array}$ & $<-$ & $\begin{array}{l}\text { Roads (bad } \\
\text { condition) }\end{array}$ & 18.618 & 31.754 & 1.786 & 0.558 \\
\hline Price & $<-$ & $\begin{array}{l}\text { Road (min } \\
\text { width) }\end{array}$ & 191.248 & $125 \cdot 324$ & 1.526 & 0.127 \\
\hline Price & $<-$ & $\begin{array}{l}\text { Road (max } \\
\text { width) }\end{array}$ & -2.065 & 16.696 & 1.824 & 0.902 \\
\hline Price & $<-$ & Rice(IR 64) & 0.537 & 0.123 & $4 \cdot 363$ & $* * *$ \\
\hline Price & $<-$ & cassava & 0.066 & 0.076 & 0.872 & 0.383 \\
\hline Price & $<-$ & $\begin{array}{l}\text { Road (bad } \\
\text { condition) }\end{array}$ & 1.722 & 4.291 & 2.401 & 0.688 \\
\hline Price & $<-$ & Classes & 9.480 & $57 \cdot 703$ & 0.164 & 0.870 \\
\hline Price & $<-$ & $\begin{array}{l}\text { Number of } \\
\text { farmers }\end{array}$ & 0.035 & 0.027 & 1.303 & 0.192 \\
\hline Price & $<-$ & $\begin{array}{l}\text { Rice } \\
\text { production }\end{array}$ & -0.016 & 0.010 & 1.764 & 0.096 \\
\hline Price & $<-$ & $\begin{array}{l}\text { Area of rice } \\
\text { field }\end{array}$ & 0.075 & 0.090 & 0.828 & 0.407 \\
\hline Price & $<-$ & $\begin{array}{l}\text { Number of } \\
\text { local } \\
\text { cooperative } \\
\text { businesses }\end{array}$ & $4 \cdot 574$ & 4.278 & 1.069 & 0.285 \\
\hline
\end{tabular}




\begin{tabular}{llllll}
\hline & & $\begin{array}{l}\text { Esti- } \\
\text { mate }\end{array}$ & S.E. & C.R. & P \\
\hline Price $<-$ & $\begin{array}{l}\text { Number of } \\
\text { poor } \\
\text { families }\end{array}$ & -0.009 & 0.044 & 2.214 & 0.831 \\
\hline
\end{tabular}

The model constructed from the regression is $\mathrm{Y}_{1}=2917.99+$ $0.54 \mathrm{X}_{1}-0.01 \mathrm{X}_{2}-0.02 \mathrm{X}_{3}-2.06 \mathrm{X}_{4}+1.72 \mathrm{X}_{5}$, where $\mathrm{Y}_{1}=$ rice price (mentari); $\mathrm{X}_{1}=$ rice price (IR 64); $\mathrm{X}_{2}=$ number of poor families; $\mathrm{X}_{3}$ = rice production (ton); $\mathrm{X}_{4}=$ maximum road width; $\mathrm{X}_{5}=$ condition of road.

Within five observed districts, people varied in their food consumption patterns. The pattern shows variation of each community's dependency on rice. People in Bantur District were more dependent on rice than people in the other four districts. People in Karangploso District were the least dependent on rice (Table 5).

Table 5 Variation in food consumption among five observed districts

\begin{tabular}{llll}
\hline No & District & Condition A & Condition B \\
\hline 1 & Bantur & $43.33 \%$ & $83.33 \%$ \\
2 & Bululawang & $86.67 \%$ & $100 \%$ \\
3 & Jabung & $93.33 \%$ & $93.33 \%$ \\
4 & Karangploso & $66.67 \%$ & $43.33 \%$ \\
5 & Sumberpucung & $63.33 \%$ & $83.33 \%$ \\
\hline
\end{tabular}

A: people having percentage of food consumption to family's total consumption higher than average ( $\%$ or respondents)

B: people having percentage of rice consumption to family's food consumption higher than average (\% or respondents)

\section{Conclusion}

From the analysis, we firstly conclude that three indicators of poverty (human poverty index, poverty gap index and poverty severity index) correlated to hard infrastructure, while the correlation of head count index was weak. Secondly, the model demonstrated the correlation between hard infrastructure and poverty to rice price by the following equation: Rice price $\left(\mathrm{Y}_{1}\right)=$ $2917.99+0.54 \mathrm{X}_{1}-0.01 \mathrm{X}_{2}-0.02 \mathrm{X}_{3}-2.06 \mathrm{X}_{4}+1.72 \mathrm{X}_{5}$, where $\mathrm{X}_{1}, \mathrm{X}_{2}, \mathrm{X}_{3}, \mathrm{X}_{4}$, and $\mathrm{X}_{5}$ represent substitutive goods, number of poor families, rice productivity, local road width, and local road condition respectively.

From this study it was apparent that there was evidence that infrastructure has an effect on poverty reduction. Three main infrastructure types that were analysed and shown to influence rural poverty (in the Regency of Malang) were the availability of clean water provision organized by a community based organization (HIPPAM), condition and distance of roads to the central district, and provision of (state enterprise) power (electricity). The condition of infrastructure also influenced the variation of food security among observed districts. The causality between infrastructure and food security was related to the availability or production of rice and the price of rice. The price of substitute goods and the condition of damaged local roads in the district were positively correlated to the local rice price, the rice price influenced the variation of food consumption and proportion of food to total consumption of families within the community. On the other hand, the number of poor families, and the maximum width of local roads negatively influenced the rice price in the five districts. Based on the consumption pattern, food security was represented by the percentage of food consumption, in particular rice consumption, to total a family's consumption.

Several suggestions that can be generated from the results are: the quality of electricity and water distribution to rural areas and the quality of road network in the regency is significant to alleviate rural poverty. The condition of the road network, in particular width and distance, is also important to influence food security (rice price) and its affordability. Therefore, by the implementation of Indonesia Government Act No 6 Year 2014, the local government and rural government must focus in developing road networks from and to paddy fields while preventing land use conversion. Electricity and water supplies for rural areas are also important to prevent job shifts to non-agricultural sectors.

\section{References}

[1] Jouanjean, M A.Targeting infrastructure development to foster agricultural trade and market integration in developing countries: an analytical review. London : Overseas Development Institute (ODI)., 2013.

[2] Timmer, P. Food Security in Indonesia: Current Challenges and the Long-Run Outlook. [Online] November 2004. http://www.cgdev.org/. Assessed in 10 May 2016.

[3] Hettige, H.When do rural roads benefit the poor and how? An in-depth analysis based on case studies. Manila: Operations Evaluation Department, Asian Development Bank, 2006.

[4] Van de Walle, D.Choosing Rural Road Investments to Help Reduce Poverty. World Development, 30 (4); 2002, pp. 575-589.

[5] Ali, Ifzal and Pernia, Ernesto M. Infrastructure and Poverty Reduction What is the Connection? Economic and research department, ADB. Manila : Asian Development Bank, 2003.

[6] Fan, Senggen and Chan-Kang, Connie.Road Development, Economic Growth, and Poverty Reduction in China. Washington DC: International Food Policy Research Institute, 2005.

[7] Bryceson, F.D., Bradbury, A. and Bradbury, T. Roads to Poverty Reduction? Exploring Rural Roads' Impact on Mobility in Africa and Asia.. 4, 2008, Development Policy Review, Vol. 26, pp. 459-482.

[8] Sullivan, C.The Water Poverty Index: Development and Application at the Community Scale. Natural Resources Forum, 2003; Vol. 27, pp. 189199.

[9] Balisacan, A. M., Pernia, E. M. and Asra, A. .Revisiting Growth and Poverty Reduction in Indonesia: What Do Subnational Data Show? Economics and Research Department, ADB. Manila : ADB, 2002. ERD Working Paper Series No. 25.

[10] Agus, F., \& Irawan. Agricultural Land Conversion as A Threat to Food Security and Environmental Quality. (2006)

[11] Vijayan, P. K.. Areal Declination of Paddy Cutivation and Its Impact on Food Security - A Study on Karripuzha Watershed - Palakkad District, Kerala. Paripex - Indian Journal of Research ; 2015;pp. 244-248.

[12] Van Dijk, M., Hilderink, H., Van Rooij, W., Rutten, M., Lan, V. C., Kartikasari, K., et al.. Land Use, Food Security, and Climate Change in Vietnam. Wageningen: DFID and DGIS.; 2012.

[13] Linquist, B., Trösch, K., Pandey, S., Phouynyavong, K., \& Guenat, D. Montane paddy rice: Development and effects on food security and livelihood activities of highland Lao farmers, 2007; Mountain Research and Development, 27(1), 40-47. Retrieved from http://search.proquest.com/docview $/ 211234364$ ?accountid $=46437$

[14] Norman, G.R. and Streiner, D.L.PDQ Statistics. Ontario : BC Decker Inc., 2003.

[15] Arbuckle, J. L.IBM SPSS Amos 16 User's Guide. Chicago: Amos Development Corporation, 2007.

[16] Worl Bank.Introduction to Poverty Analysis. Washington : World Bank Institute, 2005.

[17] WHO. Trade, foreign policy, diplomacy and health. World Health $\begin{array}{llll}\text { Organization. [Online] 2014. [Cited: } 3 \text { Nopember 2014.] } & \end{array}$ http://www.who.int.

[18] Radarpena. Indonesia Negara Pengimpor Terbesar Ketiga di Dunia Radarpena.com. [Online] o9 February 2014. [Cited: 16 December 2015.] http://radarpena.com/read/2014/o2/o9/10034/1/1/Indonesia-NegaraPengimpor-Terbesar-Ketiga-di-Dunia.

[19] Rizki, Januar. Jadi Importir Gula Nomor 3 Dunia, RI Bergantung Pada 4 Negara Ini . Gatra News. [Online] 13 January 2015. [Cited: 16 December 2015.] http://www.gatra.com/ekonomi-1/perdagangan/126584-jadiimportir-gula-nomor-3-dunia,-ri-bergantung-pada-4-negara-ini.html.

[20] Sumarto, S and Suryahadi, A.Trade, Growth and Poverty in Indonesia. Bogor : IPB, 2004.

[21] Government of Indonesia.Undang Undang No 6 tentang Desa. Jakarta : GOI, 2014. 